LAERE MIDDEL ODK

\title{
Uoverensstemmende overensstemmelse
}

En narrativ fortolkning af epistemologiske og fagdidaktiske forståelser af teknologiforståelse som fag

Af Susanne Dau, Roland Hachmann og Malte von Sehested

Korrekt citering af denne artikel efter APA-systemet

(American Psychological Association System, 7th Edition):

Dau, S., Hachmann, R. \& Sehested, M. v. (2021). Uoverenstemmende overenstemmelse. En narrativ fortolkning af epistemologiske fagdidaktiske forståelser af teknolgiforståelse som fag. Learning Tech - Tidsskrift for læremidler, didaktik og teknologi, (10), 144-168. DOI 10.7146/It.v6i10.125225 
Teknologiforståelse i folkeskolen har delvist bestået af faglige udvikleres udarbejdelse af faglige prototyper. Der har i forsøget ikke været undersøgt, hvilke epistemologiske og fagdidaktiske perspektiver disse prototypers forløbsbeskrivelser repræsenterer, hvorfor dette vil være artiklens afsæt. Artiklens undersøgelsesspørgsmål er: Hvilke epistemologiske og fagdidaktiske forståelser kan identificeres i udvalgte forløbsbeskrivelser rettet mod teknologiforståelsesfaglighed som selvstændig faglighed, og hvordan kommer disse til udtryk?

Metodisk udvælges narrativer fra ind- til udskoling på baggrund af en strukturel analyse. Den narrative fortolkning tager afsæt i Ricoeurs kritisk-hermeneutiske fortolkningsramme og består af en konfiguration (mimesis 2) af de udvalgte præfigurerede (mimesis 1) narrativer. Tekststykker og plots identificeres og fortolkes med udgangspunkt i undersøgelsesspørgsmålet. Fortolkningerne henter forklaringselementer fra styredokumenter og fokusgruppeinterviews med tekstforfattere af forløbsbeskrivelser sammenholdt med elementer fra den præsenterede teoretiske ramme. På baggrund af den konfigurative fortolkning diskuteres resultaternes skolefagsdidaktiske implikationer.

Experiments with TL in public schools have partly unfolded as a development of prototypes by professional educators. However, it has not been examined which epistemological and subject-didactic perspectives they rely on. The research question of this article is: What epistemological and subject didactic understandings are represented in selected course descriptions, and how are these expressed?

Methodologically, narratives are selected from grade 1-9, based on a structural analysis. The interpretation relies on Ricoeur's critical-hermeneutical, narrative framework and consists of a configuration (mimesis 2) of the selected prefigured (mimesis 1) narratives. Text-elements and plots are identified and interpreted according to the research question. The interpretations draw explanatory elements from steering documents and focus group interviews with the authors of the course descriptions and include elements from the theoretical framework. Based on the interpretation, the school subject-didactic contributions of the results are discussed. 


\section{Uoverensstemmende overensstemmelse}

\section{En narrativ fortolkning af epistemologiske og fagdidaktiske forståelser af teknologifor- ståelse som fag}

\section{Indledning}

Teknologiforståelse er et gryende fagfelt i Danmark. Det er fremkommet på baggrund af et ønske om, at elever og studerende på alle uddannelsesniveauer skal kunne reflektere over eget liv samt deltage kritisk og konstruktivt i et fremtidigt arbejdsliv og samfund præget af en massiv digitalisering og automatisering.

I grundskolen pågår i skrivende stund et større forsøg med udviklingen af en faglighed, der sigter imod at udvikle viden og færdigheder hos eleverne, som gør dem kompetente til det digitaliserede samfund i og uden for skolen. I forbindelse med forsøget Teknologiforståelse i folkeskolen er der udviklet 110 prototyper, der afprøves på 46 udvalgte skoler. Prototyperne sigter både mod en udvalgt fagrække, hvor teknologiforståelsesfagligheden søges integreret som en del af allerede eksisterende fag, og mod etableringen af et selvstændigt fag.

\section{Artiklens fokus og forskningsbidrag}

Denne artikel baserer sig på en kritisk-hermeneutisk undersøgelse af forløbsbeskrivelser fra de 11 prototyper. Mere konkret tages afsæt i kvalitative dokumentanalyser af 35 forløbsbeskrivelser, der repræsenterer teknologiforståelse som en selvstændig faglighed på alle klassetrin.

Gennem analyser og fortolkninger af forløbsbeskrivelserne afdækkes, hvilke henholdsvis epistemologiske og fagdidaktiske perspektiver, der ligger til grund for den faglighed, der repræsenteres i de udvalgte prototyper.

Herigennem mener vi, at det bliver muligt at kaste lys over, hvorledes fagligheden i de teoretisk forankrede og formulerede styringsdokumenter transformeres og kommer til udtryk gennem fagudviklernes formgivninger af prototyperne, som har skolepraksis som mål. Artiklen skal ikke ses som en objektiv beskrivelse, men et forskningsbidrag, 
der peger på en række fortolkninger af fagligheden, som kan støtte en fortsat udvikling af en egentlig fagdidaktik for faget. I undersøgelsen har følgende forskningsspørgsmål været guidende:

\section{Hvilke epistemologiske og didaktiske positioner kan iden- tificeres i udvalgte forløbsbeskrivelser i prototyperne ret- tet mod teknologiforståelse som selvstændig faglighed, og hvordan kommer disse til udtryk i de repræsenterede narrativer og antenarrativer?}

Narrativer og antenarrativer skal her forstås som forskellige dele af det empiriske materiale, der analyseres med afsæt i en kritisk-hermeneutisk fortolkningstradition byggende på idéerne fra den franske filosof Paul Ricoeur. I artiklen veksler vi mellem at tale om prototyperne som samlende begreb for de udviklede undervisningsforløb og forløbsbeskrivelser. Forløbsbeskrivelserne skal i artiklen forstås som det hoveddokument, der beskriver undervisningsforløbet i den pågældende prototype. Vores analyser af forløbsbeskrivelserne inkluderer ikke de lærer- og elevressourcer, der er tilknyttet som eksterne dokumenter.

\section{Teknologiforståelse i en dansk kontekst}

Forsøgets prototyper indlejrer en vifte af teknologier, metoder og tematikker. Ligeledes afspejler prototyperne en række forskellige indgangsvinkler til at arbejde problembaseret, herunder scenarier og cases, der søger at opstille Wicked Problems (Tuhkala, Wagner, Iversen \& Kärkkäinen, 2019), der betegnes som problembaserede, komplekse og virkelighedsnære problemstillinger (Caeli \& Bundsgaard, 2019).

Sideløbende med forsøgsfagets afvikling fremkommer forskellige forskere og fagpersoner med bidrag til diskussioner inden for fagfeltet. Wagner, Iversen og Caspersen (2020) redegør for, hvorledes teknologiforståelsesfagligheden bygger på internationale strømninger og en skandinavisk, objektorienteret programmeringsfilosofi. De bidrager med en helhedsmodel for computationel modellering, der søger at vise en sammenhæng mellem fagets kompetenceområder og rationale.

Caeli (2020) peger på fagets historiske ophav og beskriver, hvorledes en del af datidens diskussioner omkring datamaternes funktion og samfundsmæssige implikationer (Naur, 1967) afspejles i de diskussioner, der præger feltet i dag. Caeli og Dybdal (2020) anlægger i et skolefagdidaktisk perspektiv en operationalisering af et datalogisk syn på relationen mellem problemer, værktøjer og mennesker (Naur, 1967). 
På baggrund af et empirisk eksperiment peges der bl.a. på elevernes modstand i relation til designprocessers krav om iterative forbedringer.

Hansen (2020) påpeger, at der er en diskrepans mellem fagets og folkeskolens formål nemlig fravær af kulturel og historisk dimension, herunder menneskets samspil med naturen. Samtidig understreger han, at der i fagdokumenterne ikke er nævnt begreber som fantasi og fordybelse, men derimod analyse, erkendelse og problemløsninger.

Hansens kritik vinder også genklang hos Paaskesen \& Nørgaard (2016), der påpeger behovet for at arbejde fantasifuldt med teknologierne, og at faget bør vende sig mod et deliberativt og kreativt, skabende perspektiv uden fastlagte mål og produkter, men med en åbenhed for dialogiske og demokratiske læringsformater. Fougt \& Phillipps (2020) anlægger et scenariedidaktisk perspektiv og argumenterer for, at det scenariebaserede har en central placering i teknologiforståelsesfagets metoder og rammesætning, idet scenariebaserede undervisningsforløb trækker på domæneforståelser uden for skolen og netop derigennem understøtter tematiseringer af virkelighedsnære problemstillinger.

Fibiger (2020) tager et almendidaktisk perspektiv på fagligheden. Han påpeger en nødvendig grundlæggende didaktisk stillingtagen hos læreren, der rækker ud over skolens egne grænser samt implicerer en række nye faglige kompetencer og dispositioner, som læreren ikke råder over.

En række perspektiver tager i deres kritik afsæt i skolens dannelsesopgave, og kritiserer fagligheden for at have et snævert teknologibegreb med fokus på primært digitale artefakter, der overser den historiske udvikling, som bl.a. teknologifilosofien repræsenterer (Christensen, 2020; Hansen, 2020). Andre kritiske positioneringer stiller spørgsmål ved designtilgangen eller myndighedsbegrebet (Hansen, Skinnebach \& Thruelsen, 2019) og påpeger, at faget bærer præg af et naturfagligt (STEM) blik, der i indsnævrer faget til et kreativitetspræget datalogifag.

Overordnet ses særlig fire positioner, der bidrager kritisk og konstruktivt til diskussionen om fagligheden og legitimeringen af faget $\mathrm{i}$ skolen:

1. Det datalogiske perspektiv, der argumenterer for nødvendigheden af bestemte computationelle kompetencer.

2. Designperspektivet, der fremhæver bestemte procesorienterede metoder tilgange samt arbejdet med problemer.

3. Det skolefagsdidaktiske perspektiv, der argumenterer for faglighedens legitimering samt forskellen på basisfag og skolefag. 
4. Det almendidaktiske perspektiv, der tager et mere overordnet fokus på faglighedens legitimering i forhold skole, uddannelse, undervisning og læring.

Det er ikke artiklens ærinde at positionere sig et bestemt sted, for eller imod, de ovenstående diskurser. Det bør bemærkes, at kun ganske få af disse bidrag henviser til egentlige empiriske undersøgelser og $\mathrm{i}$ stedet beror på mere normative overvejelser og begrundelser.

Artiklens ærinde er derfor at bidrage til diskussionen gennem en mere dybdegående og empirisk forankret undersøgelse af forløbsbeskrivelserne og deres tilblivelse, som kan være både med- og modstemmende i relation til de ovenfor skitserede positioneringer.

\section{Fagdidaktiske og epistemologiske perspektiver samt vidensaspekter}

\section{Fagdidaktiske perspektiver}

Fagdidaktikken udgør fagenes betingelses- og legitimeringsgrundlag i spændingsfeltet mellem de fagvidenskabelige discipliner og almendidaktikken (Nielsen, 1998). Som Krogh, Qvortrup \& Christensen (2016) påpeger, hersker i fagene den indsigt, at det faglige indhold ikke læres på en hvilken som helst måde, og at der er særlige metoder og undervisningsformer, der knytter sig til fagligheden. Fagdidaktikken repræsenterer en metarefleksion over fagets metoder, samt hvilken faglig viden og kunnen der skal udvikles hos eleven gennem den tilrettelagte undervisning. Fagsynet og de fagdidaktiske positioner kan komme til udtryk på forskellig vis, for eksempel gennem den eksplicitte udvælgelse af stof, indhold og aktiviteter, der udgør grundlaget for undervisningen. Indikationer på fagdidaktiske overvejelser kan også komme til udtryk gennem de begrundelser, der gives for, at et særligt tema eller stof skal være genstand for undervisning. Eksempelvis gives der i prototypen Computationelle strukturer i interaktive fortællinger (side 3) en begrundelse for arbejdet med interaktive fortællinger, idet problemfeltet anskues som aktuelt for alle slags digitale artefakter, men rammesættes gennem genrekravet interaktive fortællinger.

Nielsen (1998) redegør for fire fagdidaktiske grundpositioner, hvoraf to: basisfagsdidaktik og etno-didaktik, afspejler et hovedfokus på fagets særlige videns- og problemfelter. I basisfagsdidaktikken bestemmes indholdet af fagets indre logikker og strukturer, hvor særlige indholdstemaer er særligt vigtige. Etno-didaktikken fastholder fagets blik, men legitimerer indholdsudvælgelsen ud fra et mere demokratisk perspektiv, hvor elevernes erfaringsverden og interesser 
tilgodeses. De to andre grundpositioner, udfordringsdidaktikken og eksistensdidaktikken, er styret af fagets didaktiske dannelsesforestillinger. Udfordringsdidaktikken retter fagets legitimering gennem en indholdsudvælgelse, der relaterer sig til aktuelle, samfundsmæssige problemfelter, der løses gennem projektorienterede metoder og ofte positionerer eleverne som kritisk-problemløsende. Eksistensdidaktikken tager afsæt i menneskelige grundvilkår, og indholdet udvælges ud fra problematikker, der rammesætter eksistentielle spørgsmål ved mennesket i verden. De fire didaktiske grundpositioner supplerer hinanden og kombineres ofte i mere eller mindre grad.

\section{Epistemologiske perspektiver og vidensaspekter}

Et epistemologisk fagsyn implicerer også en forståelse af, hvordan eleven lærer, og hvad viden er. I artiklen trækkes tre vidensaspekter frem, der tilsammen afspejler, hvorledes vi som mennesker tænker, erfarer og handler i verden. De tre aspekter, der her skelnes mellem, er erfaringsviden, praksisviden og propositionel viden (Dohn, 2017; Hachmann, 2020). Erfaringsviden er en kropslig forankret fornemmelse for en situation, der ikke alene er mentalt forankret i hukommelsen, men også kommer til udtryk i den måde, situationen håndteres på med afsæt i dispositioner, følelser og motiver. Erfaringsviden kan ikke reduceres til at være passiv og tilbageskuende, men bør derimod kontinuerligt opbygges gennem partikulære oplevelser. Praksisviden er knyttet til at handle i praksis med bestemte færdigheder. Handlingsperspektivet, som knytter an til færdigheder, er her vigtigt, idet det fører både tavs og artikulerbar viden med sig. Man handler ikke bare, men man handler på baggrund af, i forhold til og gennem noget. Færdigheder kan have forskellige grader af fysisk handlen, og den viden, der er tilknyttet, er tilsvarende forskellig i sin kropslighed. At programmere en Micro:bit kræver ikke den samme grad af kropslighed som at udføre et højdespring. Der er særlige teknikker, udtryksformer og regler forbundet med begge aktiviteter, der gør dem mere eller mindre veludførte. Praksisviden er ikke blot at kunne, men også at vide, hvordan man gør noget på den rigtige måde i relation til de krav og betingelser, situationen stiller. Propositionel viden er viden om noget, der kommer til udtryk gennem forskellige sproglige påstande. Sproglige påstande bygger på og tager afsæt i vores erfaringer med at handle i verden. Disse relateres til både abstrakte begreber, der tilegnes i konkrete situationer, men også til erfaringer fra tidligere situationer. Eksempler på facilitering af den propotionelle viden findes i brugen af designzoner (eksempelvis i 1. klasses forløbsbeskrivelse "Storm P- og Rube Goldbergmaskiner") og faglige begrebskort, der er arbejdet med i forløb om "Vores digitale fremtidsby" i 2. klasse. Når propositionel viden kommer til udtryk, danner erfaringsviden og praksisviden altså 
grundlaget for den meningsforståelse, der fremkommer, og som er situationel i den givne kontekst.

\section{Den fortolkningsmæssige ramme}

Metodisk baseres artiklen på dokumentanalyser (Lynggaard, 2015) af forløbsbeskrivelserne (narrativer) i udvalgte prototyper suppleret med interviews (antenarrativer) fra de fagudviklere, der har formgivet prototyperne relateret til styringsdokumenternes formulerede faglighed. Grundlaget for vores dokumentanalyser bygger på den semantiske, kritisk-hermeneutiske fortolkningstradition, som beskrevet af Ricoeur (1990). Ricoeur beskriver denne tilgang som handlingens hermeneutik, der bygger på fortolkning af tekster og disses handlingsforløb (Ricoeur, 1990, s. xi).

Som udgangspunkt for fortolkning opererer Ricoeur med mimesisbegrebet, der omfatter henholdsvis:

— Mimesis 1 (præfigurationen), der repræsenteres gennem de senere beskrevne forløbsbeskrivelser.

— Mimesis 2 (konfigurationen), der er den umiddelbare fortolkning af teksten og den første distance til den oprindelige tekst i mimesis 1.

— Mimesis 3 (refigurationen), der er fiktionel og peger ud mod fremtiden og læserens forståelse og fortolkning af teksten og konfigurationen heraf, i en ny refiguration.

Den præfigurative analysegenstand (mimesis 1) er repræsenteret ved de empiriske narrativer og antenarrativer, som er udvalgt fra forløbsbeskrivelser. Disse præfigurerede, narrative elementer undergår en semantisk fortolkning under mimesis 2, som dels peger fremad mod læsernes fortolkning (refigurationen eller mimesis 3) og dels bagud mod de præfigurative beskrivelser fra forløbsbeskrivelserne og forklaringselementer hentet fra styredokumenterne og de transskriberede interviews. En styrke ved denne fremgangsmåde er ikke at levere en færdig, strukturel og bagudrettet analyse, men at pege på fortolkninger og gå mistankens omvej (Rendtorff \& Hermansen, 2002, s. 24), som kan danne grundlag for nye fortolkninger. Analysen og heraf afledte fortolkninger har dermed et potentiale for udvikling. Desuden tillader brugen af Ricoeurs fortolkningsgreb, at vi kan nedtone vores egen bias som deltagere i forsøget og de krav om henholdsvis objektivitet og subjektivitet, som en strukturel analyse alene vil være betinget af. Der gives med andre ord et fortolkningsrum med den viden og erfaring, vi bringer med ind i nærværende artikel. 


\section{Den fortolkningsmæssige fremgangsmåde}

De præfigurative narrativer (Mimesis 1), som udvælges, kan enten være en sammenhængende tekst eller et antenarrativ: forstået som en mindre tekstdel. Denne tekstdel kan være fragmenteret, uden plots, non-lineær og usammenhængende, men forbinder tidligere historier med fremtidsorienterede perspektiver, der kan virke transformerende (Boje, 2001, 2008; Dau, 2014). Vores arbejde med narrative fortolkninger (konfigurationen) tager afsæt i den tekstlige fremstilling af forløb i teknologiforståelsesfaget, der dels angiver retning i elevernes dannelse og uddannelse til faget, og dels angiver fremtidige handlinger og aktivitet jævnfør beskrivelsen af forløbene.

Forløbsbeskrivelserne, der er genstandsfeltet for analyserne og fortolkningen, fremstilles ikke som klassiske narrativer med en begyndelse, en midte og en afslutning og med indbyggede plots. De er derimod repræsentationer, der gennem beskrivelser, metaforer og begrundelser, som træder frem i teksten, giver et grundlag for efterfølgende selektion og fortolkning af narrativer.

Som indgang til analyserne har vi systematiseret den præfigurative tekst (mimesisı) og de bagvedliggende forståelser, der i tekstform repræsenteres i prototyperne. Denne indledende strukturelle analyse baseres på det, som Ricoeur betegner som de egenskaber, der skal være til stede for i konfigurationen at undersøge tekstens plots (Ricoeur, 1990, s. 76). Systematiseringen foregik ved, at alle forløbsbeskrivelser i de 35 prototyper til teknologiforståelse som fag blev undersøgt ud fra følgende skematiske oversigt:

Tabel 1.

Kategorier for indledende systematisering.

\begin{tabular}{|c|c|c|c|c|c|c|c|}
\hline $\mathrm{Nr}$ & Prototype & Trin & $\begin{array}{l}\text { Plot og } \\
\text { metaforer }\end{array}$ & $\begin{array}{l}\text { Fagmål } \\
\text { Hvilket pro- } \\
\text { blem søges } \\
\text { løst? } \\
\text { Hvilke } \\
\text { kompeten- } \\
\text { ceområder } \\
\text { dækkes? }\end{array}$ & $\begin{array}{l}\text { Legitimering } \\
\text { Skolens } \\
\text { formål } \\
\text { Fagdidaktisk }\end{array}$ & $\begin{array}{l}\text { Fagdidaktiske } \\
\text { spor } \\
\text { Metoder } \\
\text { Stofudvælgelse } \\
\text { Indhold }\end{array}$ & $\begin{array}{l}\text { Epistemologiske } \\
\text { spor } \\
\text { Erfaringsviden } \\
\text { Praksisviden } \\
\text { Propositionel } \\
\text { viden }\end{array}$ \\
\hline
\end{tabular}


Tabel 1 blev anvendt dels til identificering af centrale plots eller antenarrativer, som adresserer dele af forskningsspørgsmålet, og dels som den første strukturering og analyse af mimesis 1-teksten med blik for de bagvedliggende præmisser, som fagudviklerne har haft jævnfør format for prototypeudvikling, designmodel, mål, begrebsramme og læseplan.

Efter den skematiske organisering blev det tydeligt, at de prototyper, der bedst favner teknologiforståelsesfagligheden over tid, er de sidst udviklede, hvilket er i tråd med Ricoeurs forståelse af narrativers grundlag for udsigelse af mening (Ricoeur, 1990, s. 3). Denne grad af udsigelse genfindes også i forløbsbeskrivelserne eksempelvis på 3 . årgang, hvor der bygges videre på tidligere forløb og opsamling af viden og færdighedsmål:

9) Fælles for de fire forløb er, at de samler op på de videns og færdighedsmål for indskolingen, som de tidligere forløb ikke er kommet omkring, herunder videns og færdighedsmål indenfor Teknologisk handleevne og Computationel tankegang. Samtidig har forløbene indtænkt en progression fra de forrige forløb i forhold til uddybning og gennemarbejdning af faglige områder fra tidligere forløb indenfor Digital myndiggørelse og Digital design og designprocesser.

(Dyrendom, Frydendahl, Klausen \& Søgaard, 2021, s. 3)

Plottet, som udledes fra narrativerne, består af dets evne til at samle detaljerne i handlingen og favne erfaringen (Når internettet flytter ind - hvem (f)lytter med, s. 76), hvorfor det netop er disse, der udledes, analyseres og fortolkes på. I plots afsløres de uoverensstemmende overensstemmelser (diskonkordant concordance) og i den cirkulære fortolkningsproces og anvendelsen af de indre og ydre referencer favnes disse i genbeskrivelsen (Ricoeur, 1990, s. 43). Dels distanceres beskrivelserne i konfigurationen, som de bliver fremstillet i artiklen her, fra den præfigurerede tekst i prototyperne, og dels peger teksten i artiklen fremad mod en ukendt fremtid og refiguration hos læserne. Udover plots identificeres metaforer i de udvalgte tekster fra prototyperne. Metaforer skal ifølge Ricoeur forstås som tæt forbundet til narrativet, idet de bidrager med sprog, aspekter, kvaliteter samt værdier, der ikke kan favnes i den deskriptive fremstilling. På denne måde fungerer metaforer som en poetisk diskurs og tekstens reference. Et eksempel på dette er overskriften på forløbsbeskrivelserne "Dear data" i 6. Klasse og "Intelligente tekstiler" i 7. klasse, som metaforisk udtrykker dels indholdet, men også overskrider en mere traditionel forståelse af henholdsvis data og tekstiler. Metaforen er sammenlignelig med det at "se som" og har magt til at afsløre "væren" (Ricoeur, 1990, s. xi) og 
dermed det epistemologiske grundlag eller dannelsestænkning. Metaforerne kan samle forståelsen på en innovativ måde, som betyder, at der afsløres relevante forudsigelser. Den indholdsmæssige analyse har fokus på fagdidaktiske og epistemologiske perspektiver, og hvorledes de træder frem såvel i forløbsbeskrivelserne som i de transskriberede fokusgruppeinterviews. Det betyder, at ikke al tekst i forløbsbeskrivelserne og fra transskriptionerne af fokusgruppeinterviews er lige relevant at se på, men kun narrativer og antenarrativer, som kan adressere disse dele. Derved bliver den narrative fortolkning selektiv i relation til artiklens formål.

Dette betyder, at selektionskriterier til valg af forløbsbeskrivelser inkluderede forløb, som kunne:

— akkumulere viden fra tidligere forløb, dvs. forløb fra henholdsvis 3 . 6. og 9. klassetrin.

— inkludere metaforiske beskrivelser samt plots, antenarrativer.

- repræsentere de gennemgående pædagogiske og fagdidaktiske overvejelser fra trinnet (jævnfør fund fra Tabel 1).

- repræsentere generiske didaktiske metoder og artefakter anvendt på trinnet (eks. begrebskort, designzoner, breaker-space/skramlotek og Micro:bit i indskolingen).

\section{Konfiguration 1: Indskoling}

I indskolingen er forløbsbeskrivelsen i prototypen "Når internettet flytter ind - hvem (f)lytter med" (Dyrendom, Frydendahl, Klausen \& Søgaard, 2021) udvalgt som analytisk genstand, da den ligger på 3. klassetrin og trækker på elevernes tidligere forløb, og fordi den adresserer viden og kompetencer, som inkluderer kompetenceområderne og giver et nogenlunde tydeligt indblik i fagligheden. Denne analytiske genstand suppleres med antenarrativer fra et interview med de tre fagudviklere (A, B og C), hvor deres retrospektive forklaringer bidrager til indsigt i deres epistemologiske afsæt og forståelse af teknologiforståelsesfagligheden.

Teknologiforståelsesfagligheden er i forløbsbeskrivelsen koblet op på elevernes tilegnelse af viden om internetsikkerhed, digitale fodspor og internettets konstruktion koblet med brugsstudier, hvor eleverne opnår færdigheder i at undersøge brugen af digitale artefakter i hverdagen. Desuden tilskynder forløbet, at eleverne kan arbejde teknisk idégenererende. Forløbet lægger ikke op til, at eleverne skal kunne ændre systemindhold og algoritmer, men i stedet at de på baggrund af analyser kan udarbejde idéer og bygge videre på andres idéer 
til re-design af de digitale artefakter, så de bliver mere sikre og fremtidssikrede. Dette afspejler forløbsbeskrivelsens fokus på, at teknologiforståelsesfagligheden skal væres meningsfuld for eleverne og tage afsæt i deres hverdag og deres erfaringer (eksempelvis med TIK TOK). Der lægges derfor ikke op til, at eleverne skal producere et digitalt artefakt, men at de gennem designprocessen, feedback og refleksioner opnår viden og kompetencer til kunne komme med forslag til forandringer på idékort.

Selve overskriften i forløbsbeskrivelsen indeholder en metafor i form af en personificering af internettet, som dermed tildeles menneskelige egenskaber; at kunne flytte ind og lytte med. Denne metafor favner læserens opmærksomhed, idet den dels italesætter en forståelse af de digitale artefakter (her internettet) som nogle, der kræver dels forståelse og dels kritisk stillingtagen, da de både flytter ind i dit hjem og lytter med på, hvad du siger. På denne måde fungerer metaforen som meningsskabende genbeskrivelse af forløbsbeskrivelsen og som metaforisk reference for, hvordan forløbsbeskrivelsen skal anskues, og hvad det betyder for elevens væren (jævnfør Ricoeur, 1990, s. xi). Brugen af metaforer og personificeringer kan tolkes som et didaktisk greb i forhold til målgruppen i indskolingen; brugen heraf favner noget fagligt abstrakt og fjernt på en mere nær måde for både elever og lærere. Samtidig lægges der hos fagudviklerne ikke skjul på, at det ikke kun handler om direkte oversættelser af styredokumenterne til undervisningsforløb, men at de også vil udvikle noget. Prototypen som forandringsimpuls bliver således også omtalt metaforisk: "Det hed sig, at det var en trojansk hest, nede på indskolingen. Det handlede om teknologiforståelse, men vi havde også så meget andet på hjerte...” (Fagudvikler B).

Forløbsbeskrivelsen beskriver, hvorledes elevernes hverdag er præget af en digital legekultur, hvor mængden af information på nettet kan være overvældende. Forløbet baserer sig således på en pragmatisk tænkning, hvor fokus er på praksis, og på hvordan virkeligheden udspiller sig i konkrete sammenhænge i relation til praksis (Løgstrup, 2020). Dette viser sig eksempelvis ved, at beskrivelsen lægger op til, at lærerne selv skal finde de rette tidspunkter, hvor de vil intervenere:

... hvor læreren løbende griber de øjeblikke, hvor det er meningsfuldt at forklare og udfordre eleverne omkring deres viden om internet og internet sikkerhed. Læreren har derfor brug for at trække på egen viden om feltet, når der løbende opstår mulighed for fælles refleksion og vidensopsamling. (Dyrendom, Frydendahl, Klausen \& Søgaard, 2021, s. 6) 
Ligesom hos Fibiger (2020) arbejdes der med et afsæt, som har fokus på lærerens didaktiske stillingtagen, hvor fordringen er, at nye didaktiske kompetencer sættes i spil. I citatet indgår endnu en metaforisk reference, hvor det fremgår, at læreren skal gribe øjeblikke, hvor gribe kan associeres med at gribe en bold eller lignende genstande. Denne metafor rammesætter og refererer til, at læreren skal finde det præcise øjeblik, hvor det findes passende at understøtte eller udfordre eleverne. Der er ikke direkte angivet hvornår eller hvordan, men udelukkende hvem, nemlig læreren. Her forventes læreren først og fremmest at anvende erfaringsviden i relation til hvornår og dernæst sin propositionelle viden i relation til hvordan.

Selvom forløbsbeskrivelsen synes at inkludere en pragmatisk tilgang, så er der også dele af forløbsbeskrivelsen, der trækker mere direkte spor til styredokumenterne: eksempelvis kompetenceområderne og designprincipperne, som på den ene side rammesætter forløbets indhold og metode og på den anden side sætter begrænsninger for en pragmatisk, mere ikke-cementeret tilgang og metode. Det kommer til at betyde, at lærerfagligheden, forstået som lærerens didaktiske frihed og teknologiforståelsesfaglighed, efterspørges, men også at den afgrænses af et på forhånd defineret design med tydelige kompetenceområder, som efterstræbes. Kompetenceområder, som også i sig selv synes at repræsentere forskellige epistemologiske traditioner. Forfatterne af forløbsbeskrivelsen har forsøgt at omgå dette så vidt muligt, idet de ønskede, at forløbet skulle bygge på elevernes dannelse og pædagogiske, almendidaktiske overvejelser:

99

Det der meget problemorienterede, virkelige problemer, det tænker jeg er noget, der lige skal tvistes, sådan at vi husker på, at det handler om børnenes virkelighed - ikk?". I virkeligheden tage det alvorligt, at det er et dannelsesfag, og det har en skabende identitet, så i virkeligheden som fag, det ligger lige så meget over i håndværksfag som det gør i de humanistiske fag, så i stedet for at sige det ligger i STEM eller de humanistiske fag, så... jeg tænker, det er dannelsesfag.

(Fagudvikler A)

Indholdet i citatet bekræftes af fagudvikler B og C. Forfatternes beskrivelse af fagligheden, giver i kraft af deres udsagn om, at faget ligger i flere områder (STEM, de humanistiske fag og håndværksfag), udtryk for den pragmatiske tænkning, som forløbene udvikles på baggrund af. Dette resulterer i, at de beskriver faget som et dannelsesfag. Ligeledes afspejler citatet et fokus på børnenes virkelighed og erfaringer (mere end komplekse samfundsmæssige problemer), og at forfatternes didaktiske grundposition mest synes at relatere til etno-didaktikken 
(Krogh \& Nielsen, 2012). Når forfatterne tidligere beskriver deres udvikling som en Trojansk hest, gives der et metaforisk billede på, hvordan de har sneget sig ind i feltet og bragt det frem, de havde på hjerte, mere end det, der måske umiddelbart var forventet. Forløbsbeskrivelsen angiver i sit formål følgende:

99 Eleverne skal i dette forløb udvikle faglige kompetencer, således at de konstruktivt og kritisk kan forstå, hvad internettet er samt forstå synlig og usynlig dataopsamling i et børneperspektiv og dets muligheder og konsekvenser med henblik på at forstå, skabe og agere meningsfuldt $i$ et fremtidigt digitaliseret samfund.

Forløbet vil også rammesætte refleksioner over internet etik og hensigtsmæssig kommunikation på internettet.

(Dyrendom, Frydendahl, Klausen \& Søgaard, 2021, s. 4)

Formålet konkretiserer således, dels hvad der skal udvikles (udviklingen af faglige kompetencer) og dels hvorfor der skal udvikles (med henblik på forståelse, skabelse og ageren). Dette synes at have en tydelig sammenhæng med det overordnede formål med forsøg med teknologiforståelse i folkeskolen, da forståelse og udvikling af kompetencer også her står helt centralt, hvilket også fremhæves af en fagudvikler:

99

Fordi, hvor styrken ligger, der ligger den i virkeligheden i formålet for teknologiforståelse. For der er beskrevet jo noget, der godt kan oversættes til en pædagogisk ramme for faget, men når man så ryger over i mål, og det gør lærerne hurtig, de ryger hurtigt over i den der mål matrix-agtige, så kan det godt virke en lille smule sådan instrumentelt og teknisk, altså de skal arbejde med netværk eller et eller andet ikk?

(Fagudvikler A)

Forfatterne problematiserer den forskydning, der foregår fra formål til mål i styredokumenterne og pointerer i ovenstående citat, at det kommer til at virke instrumentelt, hvorfor det synes at kunne afspejle en uoverensstemmende overensstemmelse som forfatterne forsøger at overvinde gennem deres egne pædagogiske overvejelser (det, de har på hjerte, jævnfør tidligere citat). De pædagogiske overvejelser adresseres som værende relaterede til følgende områder: 
...ja, nu kan vi godt brug ordet - legende,... trendy tilgang vi kan have overhovedet til undervisning - nej, men sådan hvis vi skal holde det indenfor det, vi arbejder med her, sådan en eksperimenterende eksplorativ tilgang. Jeg tror også det har noget at gøre med hvad for en kok har der lige siddet (og været udvikler)... og måske fordi vi også [de 3 udviklere] har haft forskellige styrker allesammen... og ved det vi har lavet alt sammen sammen. (Fagudvikler B)

I dette citat argumenteres der med afsæt i deres pædagogiske intentioner for forløbsbeskrivelsen, og der synes i denne sammenhæng at være paralleller dels til den tænkning om teknologiforståelse, som er beskrevet hos Paaskesen \& Nørgaard (2016) og dels til Hansen (2020) i relation til det legende og udforskende, men også i relation til den dannelsestænkning, som ikke synes at være begrænset, men trækker på forskellige fagområder (jævnfør tidligere citat om det humanistiske, håndværksmæssige og STEM). Således afspejles et pragmatisk forsøg på at imødekomme teknologiforståelsesfagligheden med afsæt i fagudviklernes kompetencer og intentioner. Dette bekræftes også af fagudviklernes italesættelse af, at de har arbejdet symfonisk med forsøgets kompetenceområder.

Den grundlæggende pædagogiske tænkning, som udviklerne har forsøgt at indlejre i prototyperne generelt og retrospektivt, er med deres egne ord rettet mod lærernes mulighed for re-didaktisering af forløbene og en pædagogisk tænkning, som tager afsæt i formålet med forsøgsprojektet og et fokus på elevernes dannelse samt det eksperimenterende, udforskende og legende.

\section{Konfiguration 2: Mellemtrin}

På mellemtrin er forløbsbeskrivelsen i prototypen "Computationelle strukturer i interaktive fortællinger" (Københavns Professionshøjskole, Læremiddel.dk, VIA University College, UCN, Rambøll, 2020) udvalgt som analysegenstand. Prototypen er en blandt fire afsluttende forløb til 6. klassetrin og formodes derfor at være udtryk for den faglige position, fagudviklerne er kommet frem til gennem arbejdet med forsøgsfaget som selvstændigt fag på mellemtrinnet. Denne analytiske genstand suppleres med antenarrativer fra et interview med de 3 fagudviklere (D, E og F), hvor deres retrospektive forklaringer bidrager til en fortolkning af deres epistemologiske afsæt og forståelse af teknologiforståelsesfagligheden.

Forløbsbeskrivelsen er typisk for de øvrige prototyper på mel- 
lemtrinnet ved at have en ret begrænset brug af metaforer. Det mere beskrivende og udfoldede metaforiske sprog optræder i højere grad i de elev- og lærerressourcer, som prototypen indeholder udover forløbsbeskrivelsen. Selve forløbsbeskrivelsen bliver således i høj grad et dokument, der over for læreren skal beskrive, hvad der skal ske, hvornår og hvorfor.

Omdrejningspunktet i prototypen er at forstå computationelle strukturer, ved at man skaber interaktive fortællinger, og forstå at disse strukturer går igen i andre digitale artefakter. Således indledes forløbsbeskrivelsen med følgende begrundelse for valget af problemfelt:

99 Bag ethvert digitalt artefakt ligger en ide, som er omsat til computationel struktur. En forståelse for computationelle strukturer er derfor essentiel i teknologiforståelsesfaget, både når eleverne forsøger at forstå eksisterende artefakters opbygning, og når de selv skal konstruere digitale artefakter og derfor skal kunne strukturere deres egne ideer computationelt.

(Københavns Professionshøjskole, Læremiddel.dk, VIA University College, UCN, Rambøll, 202O, s. 4)

Citatet beskriver, at der i arbejdet med digitale artefakter er flere didaktiske forståelser i spil, hvor forståelse relaterer til den erfaringsog praksisviden, eleverne oparbejder gennem konstruktioner. Implicit ligger heri, at den viden, der udvikles, er eksemplarisk og overførbar til andre situationer: "De computationelle strukturer, som eleverne skal arbejde med, lader sig overføre til andre typer artefakter, [...] den opnåede forståelse gennem denne prototype kan altså anvendes videre frem i mange andre sammenhænge." (Københavns Professionshøjskole, Læremiddel.dk, VIA University College, UCN, Rambøll, 202O, s. 4). Denne pointe gentages i forløbsbeskrivelsens perspektivering både i forhold til det væsentlige $\mathrm{i}$, at eleverne opnår en bevidsthed om computationelle mønstre og som eksemplarisk, ved at de fremadrettet kan gribe tilbage til denne prototype, når der skal konstrueres digitale artefakter (Københavns Professionshøjskole, Læremiddel.dk, VIA University College, UCN, Rambøll, 2020, s. 19). Udover den computationelle tænkning ligger forløbsbeskrivelsen op til, at man arbejder med digitalt design og designprocesser samt teknologisk handleevne. I forløbet arbejdes der med Twine som et værktøj til strukturering af interaktive fortællinger. Der gøres en del ud af at forstå værktøjet både gennem konstruktion eller modificering af eksisterende fortællinger, men også ved at afprøve andres fortællinger og herigennem opbygge egen forståelse af de mulige narrative forløb. I forløbsbeskrivelsens 2. udfordring (Københavns Professionshøjskole, Læremiddel.dk, VIA 
University College, UCN, Rambøll, 2020, s. 15) udvides dette unders $\emptyset$ gelses- og forståelsesarbejde til at omfatte programmering som en del af den interaktive fortælling. Da der er tale om tekstbaseret programmering, som i følge trinmålene først introduceres i udskolingen, gøres der særligt opmærksom på dette, og der peges på, at der kan skabes erfaringer, som eleverne kan bruge, når de for alvor skal arbejde med tekstbaseret programmering senere (Københavns Professionshøjskole, Læremiddel.dk, VIA University College, UCN, Rambøll, 2020, s. 6).

Forløbsbeskrivelsen gør også noget ud af at sikre elevernes forståelse af faglige begreber. Det er en del af den særlige prototypeskabelon, at man har en oversigt over centrale faglige begreber, men det understreges her, at lærere skal understøtte og stilladsere elevernes forståelse ved selv at anvende og støtte eleverne $i$ at anvende begreberne. Det er i høj grad læreren, der skal sikre dette, og det skal gøres, hvor det giver mening. Der stilles krav til underviseren om at have både en god forståelse for selve fagbegreberne, men også en forestilling om progression i elevernes viden gennem brug af specifikke sproglige ytringer og termer gennem forløbet. Der er tale om en pragmatisk tænkning, og der lægges op til basisfagsdidaktiske overvejelser i relation til arbejdet med fagbegreber og elevernes progression.

Teknologiforståelse er ikke udsprunget af en etableret faglighed, men er sammensat af flere videnskabsdiscipliner, der mødes og sammen skaber en ny faglighed. I forløbsbeskrivelsen trækkes i høj grad på datalogi. Ikke bare gennem valget af stofområde, men også gennem metoder, hvor især use-modify-create-tilgangen bliver omdrejningspunktet for elevernes bearbejdning af det faglige stof. Eksempelvis skal eleverne i forløbet tage udgangspunkt i et præfabrikeret eksempel; selv udbygge og sidenhen skabe deres egen interaktive fortælling.

De forskellige faglige forudsætninger hos fagudviklere fremhæves som afgørende for deres udvikling af prototyperne. Dette formuleres af fagudvikler D: "Så grunden til, hvor vi er nået til, hvor vi er, det er, at vi har trukket og hjulpet hinanden med vores forskellige fagligheder, og så har vi heldigvis haft noget at byde ind med, i den her...”. Fagudvikler E fortsætter: "Det har været en gave for den her gruppe, at vi har haft en datalog med, hvor jeg tænker, at det kan jeg ikke med en lærerbaggrund læse mig til eller tænke mig til eller spørge mine kollegaer om." Tilstedeværelsen af en datalog synes at forklare vægtningen af en basisfagsdidaktisk tilgang, hvor basisfagets, i dette tilfælde datalogi, struktur og indhold nedsiver i undervisningsfaget, uden at det omformes af pædagogiske teorier og hensyn (Krogh \& Nielsen, 2012). Udover denne nedsivning kan der også spores en brug af mere almene tilgange og metoder gennem en række forskellige øvelser og opgaver, der kan genfindes på tværs af skolens fag. For eksempel brugen af dobbeltcirkler til retrospektion (Københavns Professionshøjskole, 
Læremiddel.dk, VIA University College, UCN, Rambøll, 2020, s. 17). og brugen af spilelementer til idégenerering (Københavns Professionshøjskole, Læremiddel.dk, VIA University College, UCN, Rambøll, 2020, s. 16). Det at trække på eksisterende fag og deres opfattelser af viden og didaktik peger fagudviklerne også selv på:

99 Anden fagdidaktisk tekst om, hvordan man kan arbejde med programmering, som jo ligger beskrevet typisk til voksne, som man så skal lave en omformning af, qua hvad man ellers ved om didaktiske ting, fra ens andre fag (...) jeg kommer med matematikfaglig baggrund og trækker jo så en del af matematikkens didaktik ind i, hvordan jeg vil omsætte de her faglige domæner til et eller andet, der giver mening, hvordan man vil arbejde med repræsentationsformer eller abstraktion, eller hvad ved jeg? (Fagudvikler F)

Citatet oven for vidner om, at fagudvikleren selv anskuer det fagdidaktiske arbejde som et konglomerat, der dels trækker på fagudviklernes egne didaktiske og faglige forståelse, dels deres erfaringsviden og dels på deres eksisterende didaktiske kendskab og tilgange. En anden vinkel på de forskellige fagligheder, der skaber baggrund for forsøgsfaget er, at den implicitte designforståelse lægger op til en udfordringsdidaktisk tilgang, og at den ud fra denne skabte prototypeskabelon, som fagudviklerne har været underlagt, både har skabt et forsøg på retning, men også har betydet, at fagudviklerne har oplevet, at skabelonen arbejdede imod den tilgang, de ønskede til fagets vidensforståelse og didaktik:

99 Havde vi haft mere frihed til at sige, "det er sådan, vi fortolker målene, så er det sådan her vi kunne lave en prototype, den kunne skaleres på den her måde, og rent didaktisk kunne vi planlægge det og lave en rammesætning der hedder sådan og sådan, hvor der har vi været bundet af", nå men vi skal starte i et problem, og så skal vi løse det, og så skal vi også designe noget. (Fagudvikler D)

Der peges på nogle af de udfordringer, der har været i forbindelse med omskabelsen af fagligheden med styringsdokumenternes baggrund, og hvorledes disse rammer har virket begrænsende på fagudviklernes udformning af prototyperne. Især produktkravet $i$ arbejdet med digitale artefakter synes at have været en forhindring eller en uoverensstemmelse i relation til den overensstemmende beskrivelse, som er fremkommet i prototypen. 


\section{Konfiguration 3: Udskolingen}

Som analysegenstand på udskolingsniveau er forløbsbeskrivelsen fra prototypen "Appanalyse" (Hjort, Christensen, von Sehested \& Erkmann, 2021) udvalgt. Denne udvælgelse baseres på, at forløbet er det sidste af den samlede forløbsprogression på 9. klassetrin og bygger på de tidligere forløb både til 9. klasse, men også på tidligere forløb på 7 . klassetrin. Forløbet formodes at afspejle fagudviklernes faglige position, der er blevet til gennem det samlede udviklingsforløb inden for teknologiforståelsesfaget som selvstændigt fagområde i udskolingen. Denne analytiske genstand suppleres med antenarrativer fra et interview med de 2 fagudviklere ( $\mathrm{G}$ og $\mathrm{H}$ ), hvor deres retrospektive udtalelser bidrager til forklaring til deres epistemologiske afsæt og forståelse af teknologiforståelsesfagligheden.

Forløbsbeskrivelsen er overordnet set et eksempel, der i mindre grad gør sprogligt brug af metaforer og plots og i højere grad har fokus på det fagdidaktiske område i form af faglige metoder og epistemologiske perspektiver. I forløbsbeskrivelsens første sætning iscenesættes forløbet med afsæt i elevernes livsverden: "I forløbet skal eleverne analysere en af de apps, de bruger i deres dagligdag" (Hjort, Christensen, von Sehested \& Erkmann, 2021, s.3). Dermed indtages en etno-didaktisk position (Krogh \& Nielsen, 2012), der med afsæt i elevernes subjektive interesser søger at skabe en meningsfuldhed i forhold til elevernes livsverden. Forløbet foreslår selv SnapChat som genstand for elevernes analyser i forhold til at blive sig bevidst om deres egen adfærd og brug af app'en, der pt. er populær hos mange unge. I næranalyserne af sprogbrugen bliver det ligeledes tydeligt, at forløbsbeskrivelsen rummer en problematiserende undertone. Dette indikeres bl.a. ved gentagende brug af begrebet "konsekvens(er)". Eksempelvis i forløbsbeskrivelsen nævnes det, at eleverne både skal "blive klogere på den enkelte app (og de eventuelle konsekvenser, brugen af app'en har), og senere: "Endeligt skal eleverne vurdere konsekvenser for individ og samfund..." (Hjort, Christensen, von Sehested \& Erkmann, 2021, s. 3).

Brugen af et begrebet "konsekvens" er henførbar til en fagterm i den faglighed, der er defineret i styringsdokumenterne, både i fagets formål, men også i kompetencemålene, hvor det først og fremmest fremkommer under digital myndiggørelse i form af konsekvensvurderinger i forhold til digitale artefakters betydning og potentialer. Ud over konsekvensvurderinger lægges der i forløbet op til, at eleverne skal komme med forslag til mulige re-designs af enkelte elementer i app’en. I forløbsbeskrivelsen gøres der eksplicit opmærksom på, at eleverne ikke kommer ud i en reel designproces, hvor de formgiver et design og dermed ikke følger den forløbsmodel, som prototyperne normalt følger. Der er dermed en aktiv metarefleksion henvendt mod 
læreren i forhold til prototypens afdækning af fagets kompetenceområder.

Nedtoningen af den konkrete designproces genspejler en epistemologisk position, hvor der er en højere vægtning af abstrakte, kognitive processer, og hvor propositionel viden fremhæves. I forløbsbeskrivelsen påpeges eksplicit det centrale $\mathrm{i}$, at elever hele tiden stiller spørgsmål til de digitale teknologier (Hjort, Christensen, von Sehested \& Erkmann, 2021, s. 9). Eleverne skal vurdere, forestille sig og dele disse forestillinger med hinanden gennem sprogliggørelser af forslag til re-designs af enkelte elementer i den valgte app. Der er tale om former for abstraktioner, hvor eleverne modellerer løsninger på en udfordring i en proces, der ligger forud for den egentlige applikation. Der trækkes på en naturfaglig indgang til problemløsning, og prototypen kan, uden at dette ekspliciteres, ses som en måde at træne elevernes problemløsningsstrategier med afsæt i denne faglighed. Dette bekræftes også indirekte af fagudvikleren til prototypen, der påpeger: “... hele den naturvidenskabelige del er totalt drænet fra faget, som jeg ser det med mine meget stærke naturfaglige briller (...) også fordi faget kommer i... eller har jo sin start i naturvidenskabsstrategien" (Fagudvikler G). En nærliggende tolkning på ovenstående er, at prototypens indhold er et forsøg på, fra fagudvikleren side, at skabe et naturvidenskabeligt afsæt for elevernes problemløsningsstrategier og undersøgelser af den valgte app.

Prototypen kan anskues som en faglig positionering mellem kompetenceområderne digital myndiggørelse samt digital design og designprocesser. Dermed lægges der et fagligt fokus på netop disse to kompetenceområder, og prototypen må ses som et forsøg på at omsætte netop de færdigheds- og vidensmål, der knytter sig hertil.

Der er indikationer på, at digital myndiggørelse har en særlig tyngde, idet begreber fra dette kompetenceområde oversættes til direkte faglige handlinger i forløbet herunder teknologianalyse, brugsstudier og konsekvensvurderinger. I forløbets progression, sker en bevægelse fra personlig livsverden til refleksioner over konsekvenser for samfundet, der forskyder den didaktiske position fra et etno-didaktisk perspektiv til det udfordringsdidaktiske perspektiv. Denne bevægelse afspejler ligeledes den beskrevne faglighed i styredokumenterne, hvor eleverne i vid udstrækning skal arbejde med og forholde sig til komplekse samfundsrelaterede problemstillinger.

Forløbsbeskrivelsen rammesætter prototypen som en ydre struktur, der samtidig implicerer, at læreren må træffe en række fagdidaktiske valg herunder, hvilken app der tages afsæt i, men også i forhold til de øvrige ressourcer i form af faglige loops med videre, der knyttes til forløbet. Fagudviklerne henvender sig i den forbindelse til læreren gennem metakommunikation og påpeger, at der er "... rigeligt med 
materiale til at dække undervisningen, og der er samtidig lagt tilstrækkelig fleksibilitet ind, så man let kan tilpasse timetallet og få mulighed for øvrig opsamling inden fagets afslutning." (Hjort, Christensen, von Sehested \& Erkmann, 2021, s. 4). Prototypens forholdsvis faste struktur og den her fremhævede metatekst kan tolkes som et forsøg på at give læreren vide rammer for sin metodefrihed, samtidig med at der skabes en faglig stilladsering, der kan støtte læreren i forhold til stofog indholdsudvælgelse. Der ligger en normativ vurdering hos fagudvikleren, der ganske tydeligt påpeger, at læreren ikke behøver søge ud over prototypen. Dette giver forløbsbeskrivelsen og prototypen som helhed præg af at være et afgrænset og stramt forløb, hvor der er plads til lærerens justeringer, men inden for fastlagte rammer.

Prototypen som helhed bærer præg af at være en hybrid mellem et åbent idekatalog på indholdssiden og et styret undervisningsforløb på struktursiden. Denne hybriditet spores også hos fagudviklerne, hvor der netop gives udtryk for en mangel på klarhed over, hvad prototypen skal repræsentere:

99 Jeg synes, det har været en stor opgave, at få den her faglighed didaktiseret, så at lærerne reelt kan bruge den. Der har været for stort et spring. Øhm, så omkring prototyperne, det er i hvert fald at få en stærk didaktisering af fagligheden og at det kan hjælpe lærerne med at... finde hoved og hale i de hoveddokumenter, der ligger der.

(Fagudvikler G)

og

99 Er det undervisningsmateriale, er det en idé, eller er det halvfabrikat eller hvad pokker er det? Altså, og det synes jeg har været et problem hele vejen og det har været et problem i forhold til, hvad det var vi sad og lavede, ikke?

(Fagudvikler H)

Fagudviklerne påpeger, at prototypeformatet har haft en formaterende kraft på, hvordan fagligheden er blevet fortolket og didaktiseret med henblik på at støtte læreren i at arbejde målrettet med målbeskrivelserne i faget. Der peges løbende i interviewet på, at en grundlæggende udfordring er det store spring, der hersker mellem faglighedens indbyggede kompleksitet og det faglige underskud, der både ligger hos lærerne, men også hos fagudviklerne selv, der identificerer sig som henholdsvis naturfags- og almendidaktikere. 


\section{Epistemologiske og fagdidaktiske mønstre på tværs af forløbsbeskrivelserne}

I konfigurationerne af de udvalgte forløbsbeskrivelser ovenfor er der udledt nogle tværgående mønstre i relation til de beskrevne epistemologiske og fagdidaktiske perspektiver. Disse mønstre binder de uoverensstemmende overenstemmelser sammen i en ny forståelse og sammenhæng. De fortolkningsmæssige konfigurationer er et udtryk for den første distancering til præfigurative forløbsbeskrivelser, som har været underlagt vores bearbejdning. Der er derfor ikke tale om udtømmende analyser af forløbsbeskrivelserne og deres indhold, men en selektion og bearbejdning, som kan give et indblik i det fagdidaktiske og epistemologiske grundlag.

Fra et epistemologisk perspektiv har indskolingen et særligt udtalt fokus på, at eleverne skal tilegne sig håndgribelige erfaringer med teknologien, kombineret med en pragmatisk legende og eksperimentel tilgang. På mellemtrinnet er der stadig en høj vægtning af en tilegnelse af erfaringer med teknologierne, men denne står i forbindelse med den metodiske fremgangsmåde use-modify-create, hvor elevernes færdigheder og erfaringer kombineres gennem kreative og skabende processer. Derudover indgår også propositionel viden i elevernes forståelse og arbejde med fagligheden gennem evalueringer og introspektion. Udskolingen har i højere grad end indskoling og mellemtrin fokus på det propositionelle vidensaspekt, men inkluderer også erfaringsviden og praksisviden som en del af forløbet. Det epistemologiske fokus på propositionel viden kommer især til udtryk ved, at eleverne i højere grad skal forstå og anvende faglige begreber og termer som en del af diskussioner og refleksioner omkring designprocesserne. Derudover lægges der vægt på, at eleverne eksplicit kan formulere og vurdere konsekvenserne af digitalisering på mere abstrakte niveauer som "menneske og samfund". Der synes fra et progressionsperspektiv at være en forventning om, at elevernes abstraktionsevne stiger med alderen og dermed også en logik i, at viden tæt på elevens erfaringshorisont er mere udtalt i indskoling, og at den propositionelle viden er mere udtalt i udskolingen, hvor eleverne for eksempel skal arbejde introspektivt med at forklare og diskutere grundlaget for deres arbejde i højere grad end med kropslige og legende tilgange.

Fagdidaktisk afspejles der forskellige didaktiske tilgange i de forskellige prototyper. I indskolingen er der en afspejling af elementer fra etno-didaktikken, hvor prototypernes indhold mere er bestemt af elevernes erfaringsverden og rettet mod deres dannelse end bestemt af styredokumenternes ønske om mere udfordringsdidaktiske perspektiver relateret til komplekse problemstillinger og samfundsudfordringer. 
På mellemtrinnet kombineres basisfagsdidaktikken og udfordingsdidaktikken, men med vægt på førstnævnte. Dette afspejles i, at der på mellemtrinnet er et overvejende fagligt fokus på elevernes forståelse af begreber og faglige progression (og støtte hertil), som læner sig relativt tæt op ad styredokumenterne, selvom denne ramme problematiseres af fagudviklerne.

I udskolingens progression sker der en bevægelse fra personlig livsverden til refleksioner over konsekvenser for samfundet, som afspejler en bevægelse fra et etno-didaktisk perspektiv til en udfordringsdidaktik. Dette er i overensstemmelse med den beskrevne faglighed i styredokumenterne, hvor eleverne i vid udstrækning skal arbejde med og forholde sig til komplekse samfundsrelaterede problemstillinger. Ligesom på mellemtrinnet afspejler udskolingens prototype, at fagudviklerne har arbejdet i et spændingsfelt mellem naturfagdidaktiske positioneringer og almendidaktiske positioneringer delvist afledt af fagudviklernes egen baggrund og kompetencer, hvilket i højere grad er afgørende i de tilhørende elev- og lærerressourcer, men ikke i forløbsbeskrivelsen.

Både i udskolingen og på mellemtrinnet problematiseres styredokumenternes snævre rammer for udfoldelsen af forløbsbeskrivelserne, men i indskolingen har fagudviklerne i højere grad arbejdet med at overskride denne gennem deres “Trojanske hest”. På mellemtrinnet synes fagudviklerne at balancere og udfordre rammen, og i udskolingen er der i højere grad tale om tilpasning til rammen og samtidig en kritik heraf. Uanset, hvordan fagudviklerne har grebet udfordringen med at skabe uoverensstemmende overensstemmelser mellem styredokumenter og forløbsbeskrivelserne an, så har styredokumenterne præget både produktion og indhold i forløbsbeskrivelserne og dermed udgjort den baggrund, som udviklingen må ses i lyset af.

Fra et fagdidaktisk perspektiv bidrager vores undersøgelse med et fokus på, hvordan fagudviklernes fortolkninger har forskudt sig i forhold til den oprindeligt formulerede faglighed.

Generelt er der et billede af en forskydning fra et udfordringsdidaktisk udgangspunkt i de tidlige prototyper, mod et etno-didaktisk udgangspunkt med et afsæt i elevernes livsverden og umiddelbare erfaringer. De faglige kompetenceområder udfoldes med udgangspunkt i problemer og udfordringer, som eleverne i højere grad kan genkende. Denne forskydning fra udfordringsdidaktikken mod en styrket etno-didaktisk position har en betydning for den fagdidaktiske stof- og indholdsudvælgelse i prototyperne, og på den måde har prototyperne som helhed bevæget sig fra problemløsning af abstrakte virkelighedsnære problemstillinger gennem design til elevcentrerede læringsmiljøer, ligesom de har bevæget sig fra et rammestyret undervisningsmiljø til elevcentrerede kreative design, og endelig fra den kontrollerede 
styring af viden og kompetencebaseret uddannelse til et større fokus på elevernes dannelse gennem faget.

Bevægelsen mellem udfordringsdidaktik og etno-didaktik peger således på, hvorledes læreren må orientere sig og balancere forskellige didaktiske positioner som afsæt for undervisning i teknologiforståelse som selvstændig faglighed.

\section{Konklusion}

Igennem de narrative konfigurationer har vi gjort opmærksom på, at der fra indskoling mod udskoling sker en progression i de epistemologiske spor fra en overvejende konkret, legende tilgang i indskolingen til en overvejende abstrakt og problemløsningsorienteret tilgang i udskolingen. Disse fund bekræftes også i den gennemgang af forløbsbeskrivelserne, som er foretaget i den strukturelle indledende analyse (Figur 1). Samtidig har vi påpeget, at den didaktiske grundposition i forløbsbeskrivelserne har rykket sig fra primært en grundlæggende udfordringsdidaktisk position til en mere etnodidaktisk position særligt i indskolingen og på mellemtrinnet, men også i form af stofudvælgelsen på udskolingsniveau.

Forskydningen fra det legende og eksperimenterende i indskolingen til et større abstraktionsniveau i udskolingen kan til dels forklares af et syn på faglig progression og elevernes erkendelsesmæssige kompetencer og fagligheder på de forskellige trin, og til dels af forskellige fagdidaktiske orienteringer hos fagudviklerne og deres måde at arbejde og forhandle udarbejdelsen af prototyperne på. Fagdidaktisk peger dette på, at forskellige didaktiske grundlag har inspireret fagudviklerne fra det legende og udforskende i arbejdet med teknologisk forestillingskraft $\mathrm{i}$ indskolingen til mere scenariedidaktiske inspirationer og videre til naturvidenskabelige møder i udskolingen. Det interessante i denne sammenhæng er, at der i analyserne er indikationer på, at denne tendens er generel og på tværs af fagudviklernes arbejde. Vi har gennem vores konfigurationer givet et indblik i nogle af de udfordringer, der har været i relation til at overskride forskellige epistemologiske og fagdidaktiske traditioner og retninger både hos fagudviklere og i de iboende styredokumenter, som ligger til grund for forløbsbeskrivelserne. Vi har skitseret, hvorledes disse uoverensstemmende overensstemmelser har været en udfordring og en balancegang i etableringen af prototyperne. Artiklen har igennem de konfigurative fortolkninger af udvalgte forløbsbeskrivelser vist en teknologiforståelsesfaglighed, som har udviklet sig i et spændingsfelt mellem styredokumenternes 
retningsgivende mål og kompetencer, fagudviklernes fagdidaktiske (for)forståelser og fortolkninger og de grundlæggende antagelser og værdier, som fagudviklerne har båret med sig og forhandlet i gruppen af med-fagudviklere. Forløbsbeskrivelserne og de retrospektive forklaringer fra interviewene med forløbsudviklerne afspejler, hvorledes fagudviklerne har overskredet og forhandlet indlejrede modsætninger mellem egne forståelser og styredokumenternes retningsgivende anvisninger, således at forløbsbeskrivelserne fremstår overensstemmende med styredokumenternes intention og samtidigt overskrider disse.

Den overordnede udviklingstendens i forløbsbeskrivelserne peger på, at fagudviklerne har haft et etno-didaktisk afsæt med deres respektive fag- og dannelsessyn, der er blevet udfordret af styrringsdokumenternes overvejende afsæt i basisfags- og udfordringsdidaktikken.

\section{Referencer}

Boje, D. M. (2001). Narrative methods for organizational \& communication research. Sage.

Boje, D. M. (2008). Storytelling organizations. Sage.

Caeli, E. N. (2020). Teknologiforståelse (1. udg.). Aarhus Universitetsforlag.

Caeli, E. N., \& Bundsgaard, J. (2019). Computational thinking in compulsory education: A survey study on initiatives and conceptions. Educational Technology Research and Development. https://doi.org/10.1007/s11423-019-09694-z

Caeli, E. N. \& Dybdal, M. (2020). Teknologiforståelse i skolens praksis. Tidsskriftet Lcering og Medier (LOM), 12(22). https://doi.org/10.7146/lom.v12i22.115613

Christensen, O. (2020). Teknologi og forståelse. Unge Poedagoger, 81(1), 15-24.

Dau, S. (2014). The use of the threefold mimesis. Akademisk kvarter/Academic Quarter, 112-125.

Dohn, N. B. (2017). Epistemological concerns - querying the learning field from a philosophical point of view [doktordisputats]. Syddansk Universitet.

Dyrendom, K., Frydendahl, J. A., Klausen, M. T. \& Søgaard, P. (2021). Teknologiforståelse som fag 3. Klasse, 2 forløb. Når internettet flytter ind - hvem (f)lytter med. Lokaliseret [02.02.21] på: https://xn--tekforsget-6cb.dk/wp-content/ uploads/2021/o6/2.-N\%C3\%A5r-internettet-flytterind-3.-kl-SOM-FAG-27-o5-2021. pdf

Fibiger, J. (2020). Teknologiforståelser: Filtret ind i og ud af teknologiens verden. Samfundslitteratur.

Fougt, S. S. \& Philipps, M. R. (2020). Teknologiforståelse - I et scenariedidaktisk perspektiv. Hans Reitzel. 
Hachmann, R. (2020). Didactic Design for Transformations of Subject-content Knowledge: An investigation of student teachers' transformations of subject-content knowledge between professional education and practice [ph.d.-afhandling]. Syddansk Universitet.

Hansen, T. I. (2020). Teknologiforståelse som praktisk klogskab. Unge Poedagoger, 81(1), 25-35.

Hansen, T. I., Thruelsen, D. K., \& Skinnebach, L. H. (2019). Socio-teknologisk fantasi og formåen: Et dobbelt didaktisk perspektiv på teknologiforståelse i læreruddannelsen. Studier i Loereruddannelse og Profession, 4(1), 5-27.

Hjort, M., Christensen, B. R., von Sehested, M. \& Erkmann, M. (2020). Teknologiforståelse som fag 9. klasse, 3. forløb, AppAnalyse. Lokaliseret [02.02.21] på: https://xn--tekforsget-6cb.dk/wp-content/uploads/2020/o6/3.-AppAnalyse-9.klasse-SOM-FAG.pdf

Krogh, E., \& Nielsen, F. V. (red.) (2012). Sammenlignende fagdidaktik 2. Cursiv.

Krogh, E., Qvortrup, A. \& Christensen, T. (2016). Almendidaktik og fagdidaktik. Frydenlund.

Københavns Professionshøjskole, Læremiddel.dk, VIA University College, UCN \& Rambøll (2019). Didaktiske prototyper format og vejledning. https://tekforsøget.dk/ forlob/som-selvstaendigt-fag-mellemtrin/

Københavns Professionshøjskole, Læremiddel.dk, VIA University College, UCN, Rambøll (2020), Teknologiforståelse mellemtrin 6. klasse, Computationelle strukturer i interaktive fortcellinger. Lokaliseret [02.02.21] på: https://xn-tekforsget-6cb.dk/forlob/som-selvstaendigt-fag-mellemtrin/

Lynggaard, K. (2015). Dokumentanalyse. I: S. Brinkmann \& L. Tanggaard, (2015). Kvalitative metoder: En grundbog (2. udgave), s. 153-167. Hans Reitzels Forlag.

Løgstrup, L. B (2020). Pragmatisme. Læremiddel.dk. Lokaliseret 18. januar, 2021, på https://laeremiddel.dk/wp-content/uploads/2021/o4/Pragmatisme_ printversion_2020.pdf

Naur, P. (1967). Datamaskinerne og samfundet. Munksgaard.

Nielsen, F. V. (1998). Almen musikdidaktik. Akademisk Forlag.

Paaskesen, R. B. \& Nørgård, R. T. (2016). Designtænkning som didaktisk metode: Læringsdesign for teknologisk forestillingskraft og handlekraft. Tidsskriftet Loering og Medier (LOM), 9(16). https://doi.org/10.7146/lom.v9i16.24201

Rendtorff, J. D. \& Hermansen, M. (2002). En hermeneutisk brobygger: tekster af Paul Ricoeur. Klim.

Ricoeur, P. (1990). Time and narrative (genoptrykt). The University Chicago Press.

Teknologiforståelse i folkeskolen. (2021). Om forsøget med teknologiforståelse i folkeskolen. Lokaliseret den 3. februar, 2021, på: https://tekforsøget.dk/omforsoget/

Tuhkala, A., Wagner, M-L., Iversen, O. S. \& Kärkkäinen T. (2019). Technology Comprehension - Combining computing, design, and societal reflection as a national subject. International Journal of Child-Computer Interaction, 20, 54-63. https://www.sciencedirect.com/science/article/pii/S2212868918301016

Wagner, M-L., Iversen, O. S. \& Caspersen, M. E. (2020). Teknologiforståelsens rationale: På vej mod computationel empowerment i den danske grundskole. Unge Pcedagoger, (1). https://u-p.dk/vare/2020-nr-1/ 